\title{
Scytonematopsis contorta sp. nov. (Nostocales), a new species from the Hawaiian Islands
}

\author{
Melissa A. VAcCARIno* \& Jeffrey R. Johansen \\ Department of Biology, John Carroll University, University Heights, OH 44118 USA; *e-mail: vaccarino_m@ \\ yahoo.com
}

\begin{abstract}
Scytonematopsis KISELEVA is a poorly known cyanobacterial genus with a widespread, mostly tropical distribution. A new species, S. contorta, is described from the Hawaiian Island of Oahu based on morphological and molecular evidence. The new species was found growing on rock in damp aerial habitats proximal to streams and waterfalls. It differs in several regards to the other 14 species, in particular in its pronounced ability to produce a spirally contorted trichome within a single filament. The phylogenetic placement of the genus is uncertain. It is associated with both Rivularia and Calothrix species in the Rivulariaceae, and is distant from the Scytonemataceae, where it has traditionally been placed. However, the relationship of these taxa is unresolved, as there was very little support for the deeper nodes of the phylogeny.
\end{abstract}

Key words: 16S-23S ITS, Calothrix, Cyanobacteria, Hawaii, Oahu, Rivularia, Scytonema, Scytonemataceae, Scytonematopsis, secondary structure

\section{Introduction}

Scytonematopsis KiseleVA (1930) is a heterocytous cyanobacterial genus diagnosed by isopolar growth; false branching (mostly geminate), and tapering towards the apices. Some species taper to clear end cells and some species form akinetes, but these features are exceptional rather than typical. ANagnostidis \& KomÁReK (1989) placed Scytonematopsis in the Scytonemataceae based on its isopolar growth. The genus contains many species that were originally described in the genera Scytonema (which does not taper) and Calothrix (which is heteropolar). Scytonematopsis currently encompasses both freshwater and marine taxa. Kiseleva (1930) designated the type species as $S$. woronichinii, which was isolated from rice fields from Turkestan. Since then, thirteen more species have been recognized. These include mostly tropical species, from paddy fields, marine waters, and forest soils. One taxon was described from a lake in the High Tatra Mountains (KovéčIK \& KomÁreK 1988), and two thermal taxa were described from Yellowstone National Park (Copeland 1936) and Japan (Емото \& Hirose 1952). Taxonomically invalid synonyms of the genus include Tildenia PolJANSKIJ, which is a later homonym of a group of herbs belonging to the Piperaceae, and Setchelliella DETONI(1936), which is simply a later synonym of Scytonematopsis.

Despite the diversity of species in the genus, Scytonematopsis is poorly known. The species are published in a very scattered literature. No synthetic treatment of the genus is available. Only a small ( $\sim 326 \mathrm{bp})$ fragment of the 16S rRNA gene is available from one unillustrated, undescribed Scytonematopsis growing on buildings in Brazil (CRISPIM et al. 2006). There is certainly a need for further study on this interesting clade of tapering Nostocales.

During a survey of the freshwater algae of the Hawaiian Islands, two distinct populations of Scytonematopsis, comprised of a single new species, have been found in waterfall splash zones on Oahu, Hawaii. This species is distinct from all previously described species attributed to the genus. In this paper, we characterize and describe the species using morphological data and report its phylogenetic placement in the Nostocales using 16S rRNA sequence data and secondary structure of the 16S-23S ITS region. The name we propose is Scytonematopsis contorta sp. nova, and we will refer to this taxon by that epithet in the remainder of this paper. 


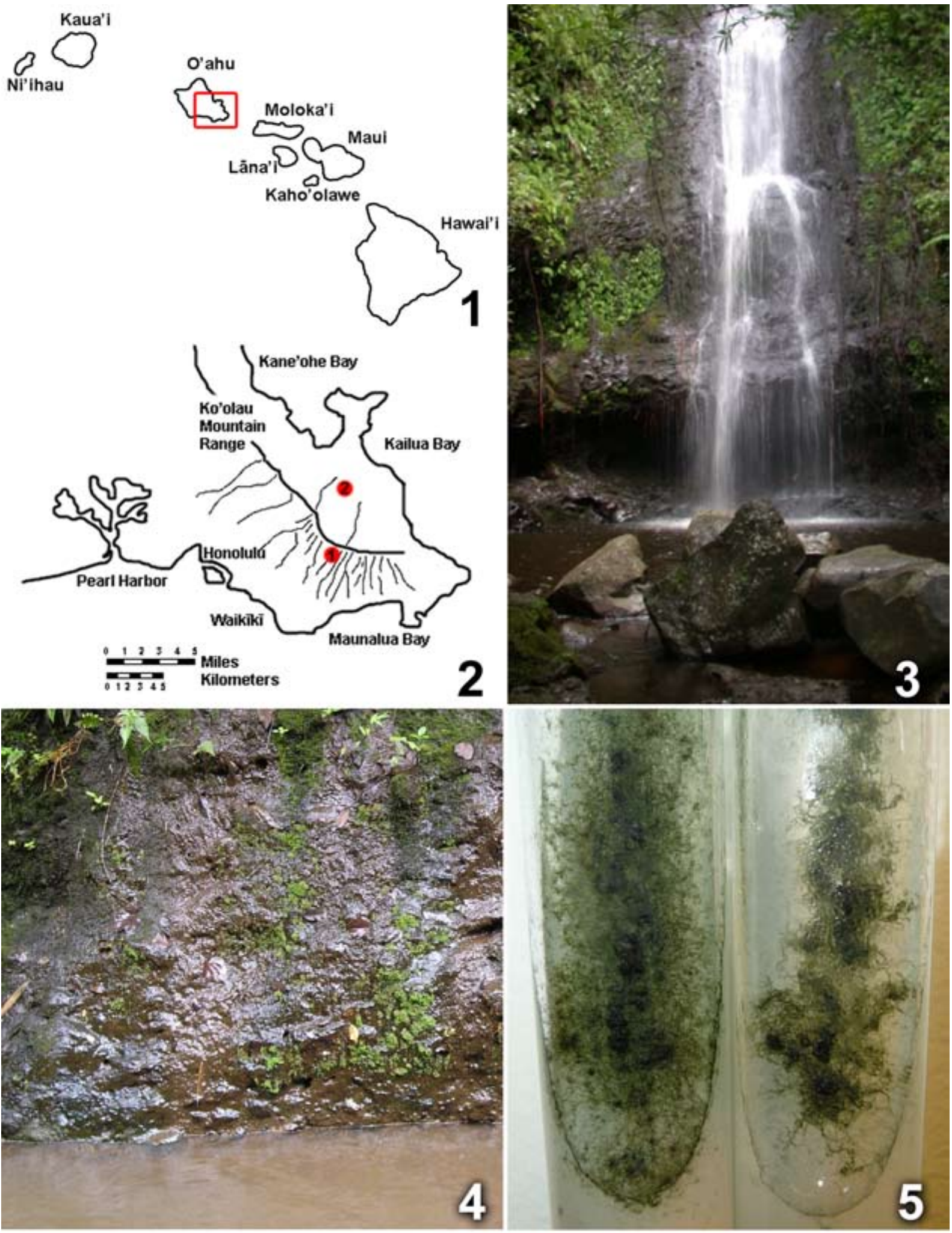

Figs 1-5. Map, site photos, and growth form of Scytonematopsis contorta: (1) The Hawaiian Archipelago, southern tip of O'ahu is boxed in red; (2) southeastern region of O'ahu, dots represent locations of sites from which S. contorta was isolated; (3) site 04267, waterfall in Palolo Valley; (4) site 04292, wet wall along Maunawili stream; (5) pure cultures of $S$. contorta showing growth form on agar, HA4267 right, HA4292 left. 


\section{Materials and Methods}

Samples were collected in July 2009 (dry season). Samples were placed in whirlpak bags or small eppendorf tubes, and then partitioned among collaborators. Environmental samples were vouchered in $2.5 \% \mathrm{CaCO}_{3}$-buffered glutaraldehyde and deposited in the Bernice P. Bishop Museum. Fresh material was kept for culturing at John Carroll University. Details of current and progressive environmental and isolate collections can be found online at the Hawaiian Algal Database webpage: http://packrat.stjohn.hawaii.edu/ hfwadb/index.html.

Site Descriptions. Sites containing $S$. contorta were located on the southeastern tip of O'ahu (Fig. 1), at the end of the Ko'olau Mountain Range (Fig. 2). The first population was collected from the first major waterfall in Wai'oma'o Stream (the east branch of Palolo Stream) accessed via the Palolo Valley Trail, headed up towards Ka'au Crater (Fig. 3). This site was approximately at $21^{\circ} 18^{\prime} 50^{\prime \prime} \mathrm{N}$ latitude, $157^{\circ} 46^{\prime} 44^{\prime \prime} \mathrm{W}$ longitude, and the environmental accession number was 04267 . The sample consisted of mud scraped from the cave-like formation behind the waterfall. The second population was geographically near the first site, but separated by the Ko'olau Ridge in a different watershed. It was collected from a wet wall along Maunawili stream, approximately 50 meters downstream from Maunawili Falls (Fig. 4). The site was approximately at $21^{\circ} 20^{\prime}$ $52^{\prime} \mathrm{N}, 157^{\circ} 46^{\prime} 28^{\prime \prime} \mathrm{W}$, and the environmental sample was accessioned as 04292 .

Laboratory work. Fresh samples were inoculated onto Z8 medium (CARMICHAEL 1986) agar plates and grown under low light $(<200 \mu \mathrm{E})$ conditions. Colonies were picked after an extended growth period (1-2 months or more) and isolated into pure culture for microscopy and molecular analysis. Both strains were characterized using an Olympus BX60 photomicroscope with high resolution Nomarski DIC optics.

Approximately $25-30 \mathrm{mg}$ of healthy culture cells were used for DNA extraction using the UltraClean Microbial DNA Isolation Kit from MO BIO Laboratories, Inc (Carlsbad, CA, USA). DNA was eluted into $50 \mu \mathrm{l}$ of solution MD5 and stored at $-20^{\circ} \mathrm{C}$. The 16S-23S internal transcribed spacer (ITS) region of the rRNA operon was amplified using primers 1 and 2 (BOYER et al. 2001, 2002). A $25 \mu \mathrm{L}$ reaction for each strain was run in a $\mathrm{C} 1000$ Thermocycler (BIORAD). The PCR cycle was carried out as follows: $95^{\circ} \mathrm{C}$ for 5 minutes; followed by 35 cycles of: $95^{\circ} \mathrm{C}$ for 1 minute, $57^{\circ} \mathrm{C}$ annealing temperature for 45 seconds, and $72^{\circ} \mathrm{C}$ for 4 minutes; ending in an additional 5 minutes at $72^{\circ} \mathrm{C}$ and finally an indefinite hold at $4^{\circ} \mathrm{C}$. The final concentrations of reagents used were as in LUKEŠOVÁ et al. (2009). PCR products ( $1600 \mathrm{bp})$ were cloned using a Strataclone PCR cloning kit (La Jolla, CA,
USA), which utilized cloning vector $\mathrm{pSC}-\mathrm{A}-\mathrm{amp} / \mathrm{kan}$. Vector DNA was isolated from clones using a QIAprep Spin Miniprep kit from QIAGEN. Plasmids containing inserts were sent to Functional Biosciences (Madison, WI, USA) for sequencing with primers M13 forward, M13 reverse, 3, 5, and 8 (BOYER et al. 2001, 2002). The program Sequencher (v. 4.1) was used to edit and proofread the sequences.

Phylogenetic Analysis. Phylogenetic analysis was based on a 1123 fragment of the 16S rRNA gene (bp 359-1482). The taxa used included a total of 106 OTUs, with 25 OTUs being novel sequences from Hawaiian freshwater/subarieal strains, 5 OTUs from Utah soil strains, and 76 OTUs from GenBank. Cyanobacteria belonging to the Nostocaceae, Microchaetaceae, Rivulariaceae, Scytonemataceae, and Stigonemataceae were chosen for comparison (encompassing taxa with heterocytes which exhibit no branching, false branching and/or true branching). Three trees were constructed using parsimony, distance, and maximum likelihood analyses in PAUP v.4.02b (SwOFFord 1998). Parsimony was run using heuristic search settings with simple addition sequence, nearest-neighbor interchange for branch-swapping, and steepest descent. Bootstrapping was conducted with 1000 replicates. Maximum likelihood was run using the general time reversible model, and bootstrapped with 100 replicates. Distance was run using distance measure HKY85, gamma distribution with default shape parameters, nearestneighbor-interchange branch-swapping algorithm, and steepest descent. Bootstrapping for this tree used 1000 replicates.

Secondary structures of the $16 \mathrm{~S}$ internal transcribed spacer (ITS) region were determined for several taxa present in the phylogeny and used for comparison (novel sequences and several from GenBank). These structures were transcribed and folded for all available operons (with and/or without tRNA) using the Mfold web server (ZUKER 2003). Images of these structures were drawn using Adobe Illustrator CS3 (ver. 13.0.0).

\section{Results}

\section{Scytonematopsis contorta, sp. nov. (Figs 5-17)}

Diagnosis: A S. terrestris cellulis multo brevioribus differt. S. shankargarense simile, sed trichomis parum latioribus vagina multo angustiore. A speciebus omnibus generis trichomis dense torsivis et ramificatione geminata profusa differt.

Descriptio: Coloniae griseovirides, nonnitentes, effusae a centro, filis paucis erectis a agaro. Fila dense intricata, undulata, trichoma singula, pseudoramificatione geminata frequenti, pseudoramificatione singula rara, 14-30 $\mu \mathrm{m}$ lata. Vagina angusta, hyalina, in luce vivida 
fulvescens, non lamellata. Trichomae initio isopolares, apicibus ambabus gradatim angustatis ad extremum obtusum, spirae densae in centro fili formantes, non constrictae vel leviter constrictae ad septa, post fragmentationem heteropolarescentes heterocystis basalibus interdum formantibus, ad trichomam mediam 9-12-(13) $\mu \mathrm{m}$ latae, angustatae gradiatim ad 3-4.0 $\mu \mathrm{m}$ latae, pilo non angustatae. Cellulae nongranulatae vel leviter granulatae, in trichoma media saepe breviorae quam latiorae, impigre cresentes, $1.5-3$ (-6.0) $\mu \mathrm{m}$ longae, in parte angustata trichomae plerumque isodiametrae vel longiorae quam latiorae, non dividentes, pigmentosae, 3-6 4 m longae. Heterocystae rariorae, terminales vel intercalares, stramineae, globosae, compressae, lunatae vel irregulares, 4-8.5

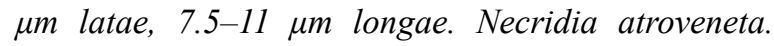
Akineta in seriebus formantes, irregulare ad regulare connexa, rotundata vel ellipsoidalia, vacuolatescentia, saepe cellulis dividentibus in partibus lunatis duabus, a vagina firma aperta emergentia, 8.5-12 $\mathrm{m}$ lata, 3-10 um longa.

English Diagnosis: It differs from $S$. terrestris by its much shorter cells. Similar to $S$. shankargarensis but with slightly wider trichomes and a much narrower sheath. Differs from all species in the genus by its dense coiling and profuse geminate branching.

English Description: Colony grayish green, nonshiny, spreading far from center, with few filaments erect from agar. Filaments densely entangled, wavy, with a single trichome per filament, with frequent double false branching, with rare single false branching, 14-30 $\mu \mathrm{m}$ wide. Sheath thin, hyaline, becoming golden brown in high light, not lamellated. Trichomes at first isopolar, both ends gradually tapered to a blunt end, forming dense spirals in center of filament, unconstricted to slightly constricted at the crosswalls, becoming heteropolar following breakage, sometimes developing basal heterocytes following breakage, 9-12-(13) $\mu \mathrm{m}$ wide at midtrichome, tapering very gradually to $3-4.0 \mu \mathrm{m}$ wide, not tapering to a hair. Cells ungranulated or slightly granulated, in midtrichome frequently shorter than wide, actively growing, 1.5-3 (-6.0) $\mu \mathrm{m}$ long, in tapered region of trichome mostly isodiametric to longer than wide, not dividing, fully pigmented, 3-6 $\mu \mathrm{m}$ long. Heterocytes rare, terminal or intercalary, yellowish, round, compressed, crescent shaped, or irregular, 4-8.5 $\mu \mathrm{m}$ wide, 7.5-11 $\mu \mathrm{m}$ long. Necridia dark bluish-green. Akinetes formed in series, irregularly to regularly connected, round or ellipsoidal, becoming vacuolated, often with a single round cell divided in two halves, emerging from an open, firm sheath, $8.5-12 \mu \mathrm{m}$ wide, $3-10$ $\mu \mathrm{m}$ long.

Type Location: Wai'oma'o Stream, Palolo Valley, O'ahu, Hawai'i, $21^{\circ} 18^{\prime} 50^{\prime \prime} \mathrm{N}$ latitude, $157^{\circ} 46^{\prime}$ $44^{\prime \prime W}$ longitude. Subaerial on wet rock walls and waterfall splash zones.

Holotype here designated: Scytonematopsis contorta HA4267-MV1 BISH 747428.

Paratype here designated: Scytonematopsis contorta HA4292-MV4 BISH 747429.

Reference Strain: Scytonematopsis contorta HA4267-MV1 (UTEX Culture Collection, Austin, Texas, U.S.A.).

Scytonematopsis contorta has a very distinct ontogeny. Young filaments are isopolar and tapered at both ends (Figs 6-8), similar to the oscillatorialian genus Ammatoidea (KOMÁREK \& Anagnostidis 2005) and the Pseudanabaenalean species Tapinothrix clintonii BoHUnickÁ et JoHANSEn (BohunickÁ et al. this issue). As the filaments mature, the trichomes typically begin to coil within the sheath, creating contortions that cause numerous false branches to occur in close proximity to one another (Figs 6, 10, 12-14). While most branching is geminate, single false branching also occurs (Fig. 11). When single false branches arise, fragmentation can occur, yielding trichomes that appear heteropolar, with a widened base and tapering apex (Figs 9, 11). When terminal heterocytes develop in these heteropolar filaments, they are indistinguishable from Calothrix (Fig. 9). However, basal akinetes never develop near these terminal heterocytes, a feature which distinguishes Scytonematopsis from Calothrix. Indeed, akinetes are very unusual in this taxon as they develop apically in series (Figs 15-17), and have the rather unique characteristic of dividing to produce hemispherical cells (Figs $15,17)$. Akinetes are additionally distinguished by their vacuolated appearance (Fig. 17). Because of the different life-cycle stages, one could imagine that field material of Scytonematopsis could likely be confused with Ammatoidea or Calothrix, but if the tapering apices were not ignored it would be unlikely to be confused with Scytonema or Brasilonema in the Scytonemataceae.

The tight coiling of the trichome within the middle regions of the sheath appears to be a genetically determined trait characteristic of at least a number of species of Scytonematopsis. The feature has been well illustrated for Tildenia dura (Kosinskaja 1948), S. incerta (Geitler 1933), 
and Scytonematopsis ambigua (Емото \& Hirose 1952). GeitLer $(1932,1933)$ made mention to the irregularly coiled filaments of both S. fulginosa (as Tildenia fulginosa), and S. incerta, but considered the feature taxonomically unimportant. Because he considered it unimportant, he did not include the feature in the diagnoses of the species he treated. The trait has been illustrated in Rivularia species from the Baltic Sea (Sinvonen et al. 2007, fig. $1 \mathrm{j}$ ), and we suspect that the ability to produce such coiling may be genetic (and therefore taxonomically important), but the degree of expression is likely environmentally plastic. For now, the intensity of the coiling and profuse branching in $S$. contorta distinguishes it from the other species (Table 1).

Scytonematopsis contorta is distinctive from many of the other species in this genus (Table 1). S. contorta is ecotypically distinct in that it occupies quite a different biotope from all other members of this genus. Of the other freshwater members this is the only one located in splash zones near fast flowing water, where the majority of them are from paddy fields, and S. starmachii and $S$. kashyapi are from stagnant waters. The rest of the genus is comprised of marine taxa, two thermal taxa (S. ambigua and S. hydnoides), and one from sedimentary soil (S. neocaledoniense). Another species, S. variabilis YONEDA nom. nudum (YoNEDA 1952) was mentioned but not described properly (UMAZAKI \& WATANABE 1994), and therefore has no taxonomic status. In terms of morphology $S$. contorta differs from many of the other species in that the colony is flat and creeping, the trichome is very thin as well as the sheath, and the end cells are pigmented. The cells midtrichome are quite short, and are never nearly as long as several other non-marine species that have a similar trichome width. The trichomes in the regularly-sized midregion are most similar in size to those of $S$. shankargarensis and $S$. terrestris. $S$. contorta differs from $S$. shankargarensis by having more acute tapering, a thinner and nonlamellated sheath, and a slightly thicker trichome; from $S$. terrestris in that the cells are much shorter in length; and from both in that apical cutting (see Pandey \& Mitra 1972) was not observed. The akinetes are comparable in appearance to $S$. hydnoides in shape and arrangement, however they were never observed midtrichome in our species.

\section{Phylogenetic Analysis}

Seven clones of the rRNA gene of Scytonematopsis (3 from HA4267-MV1 and 4 from HA4292MV4) were sequenced. One clone from each strain of Scytonematopsis was identical in the entire sequenced 16S rRNA gene fragment and 16S-23S ITS region. We assume these represent homologous operons in the species. Among the rest of the cloned sequences, $12 \mathrm{nt}$ (dispersed throughout the gene) were non-congruent. None of the operons recovered had either tRNA gene in the ITS region. We conclude that both strains belong to the same species.

The topology of the parsimony, likelihood and distance analyses were very similar, particularly with reference to Scytonematopsis, Scytonema, Brasilonema, and Calothrix. We show the parsimony analysis with node support from all three analyses (Fig. 18). Thirty-one OTUs clustered basally in the tree and were mostly comprised of members of the Nostocaceae. We considered these to be our outgroup taxa for all analyses.

Based on the taxon sampling available at present, the Scytonemataceae, Rivulariaceae, and Stigonemataceae were not well resolved. The Stigonemataceae formed a fairly monophyletic clade, except for three OTU's including two Calothrix species and Chlorogloeopsis (Fig. 18). The Scytonemataceae sensu stricto (Fig. 18, clade A) included seven Scytonema OTU's and eight Brasilonema OTU's. Scytonematopsis contorta formed a clade with two Petalonema strains (Fig. 18, clade B), but was separated from the Scytonemataceae by a group of Rivulariaceae (Calothrix and Rivularia, Fig. 18, clade C). Microchaetaceae was sister to the clade containing all of these clades. Three additional Rivulariaceae (Gloeotrichia and Calothrix) occur in a basal position to the branching Nostocales. Calothrix was the most clearly polyphyletic genus, occurring in four distinct clades. It seems apparent that the characteristic of tapering trichomes has likely arisen more than once in the Nostocales, as taxa with that trait do not form a monophyletic group.

Node support was weak along the spine of the phylogenetic analyses. Only the family Stigonemataceae had strong support. The familial relationships of all other taxa are in doubt. While the two populations of Scytonematopsis are certainly the same species, the placement of this genus in the Scytonemataceae is unsupported. Even if the Rivulariaceae and Scytonemataceae 


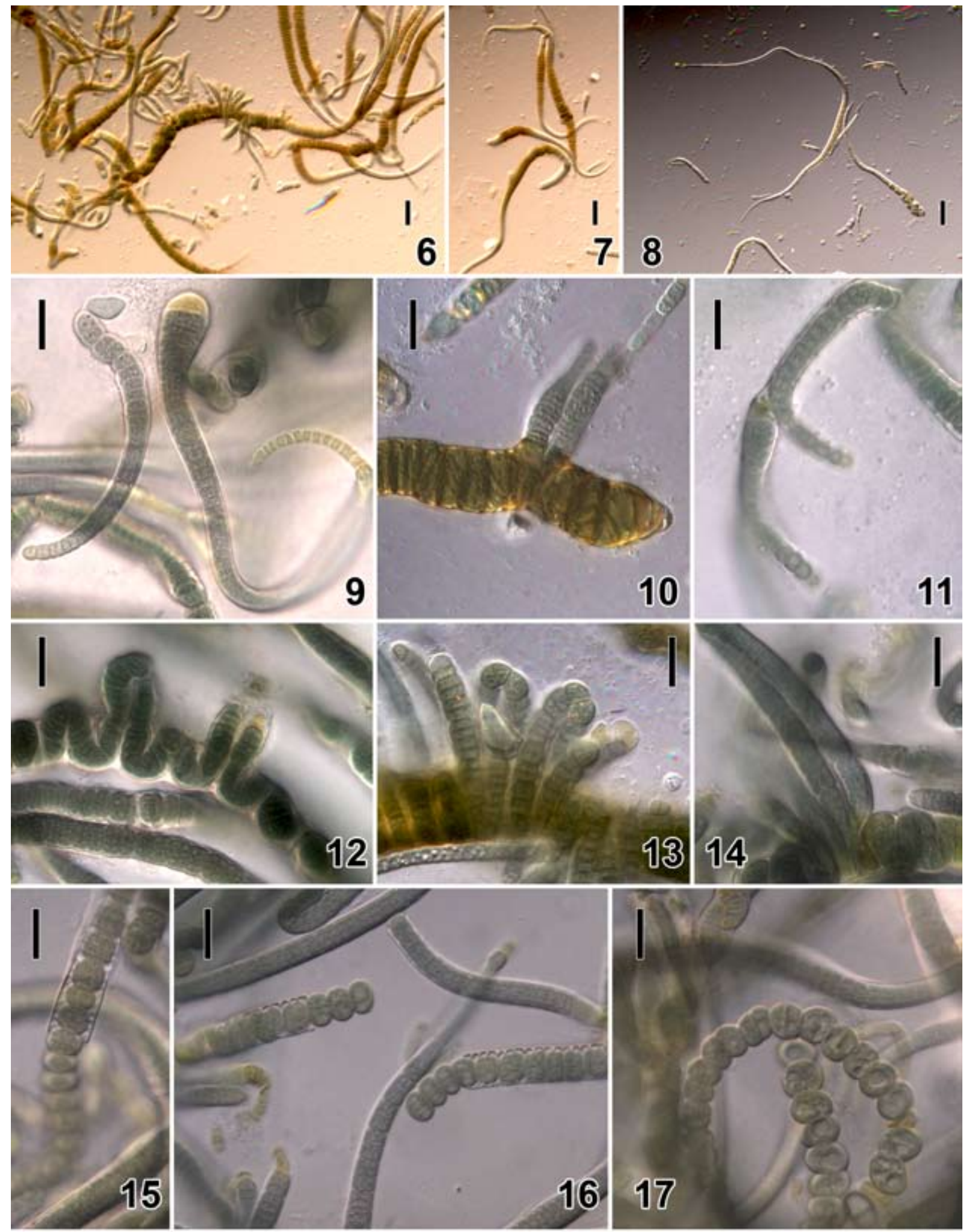

Figs 6-17. Light micrographs of Scytonematopsis contorta: (6) growth habit, showing dense coiling trichomes with subsequent profuse branching, scale $50 \mu \mathrm{m} ;(7,8)$ isopolar trichomes tapered to both ends, scale $50 \mu \mathrm{m}$; (9-17) scale bar 20 $\mu \mathrm{m}$; (9) heteropolar "Calothrix-like" appearance; $(10,13,14)$ profuse coiling and geminate branching; (11) rare single false branching; (12) geminate false branching; $(15,16)$ formation and release of spores from sheath; (17) vacuolization of spores. 
Table 1. Scytonematopsis - Currently accepted and possibly related species [(Ref) References/Authors: (1) KovéčiK \& KomÁreK 1988; (2) Copeland 1936; (3) Tilden 1910; (4) Umezaki \& M. Watanabe 1994; (5) Emoto \& Hirose 1952; (6) Akiyama 1977; (7) Geitler 1933; (8) this paper; (9) Pandey 1965; (10) Varma 1974; (11) Geitler \& Ruttner 1935; (12) Couté, Tell \& Thérézien 1999; (13) Kiseleva 1930; (14) Desikachary 1959; (15) (Mertens) C. Agardi ex Bornet et Flahault 1886; (16) Harvey ex Setchell et Gardner 1919; (17) Bornet \& Flahault 1886; (18) KOSINSKAJA 1948].

\begin{tabular}{|c|c|c|c|c|c|}
\hline Species Name & $\begin{array}{l}\text { Filament } \\
\text { width }(\mu \mathrm{m})\end{array}$ & $\begin{array}{l}\text { Trichome } \\
\text { width }(\mu \mathrm{m})\end{array}$ & Habitat/Described From & Diagnostic characters & Ref. \\
\hline \multicolumn{6}{|l|}{ Marine } \\
\hline $\begin{array}{l}\text { S. crustacea } \\
\text { Syn Calothrix }\end{array}$ & $12-20(40)$ & $8-15$ & Widespread Distribution & $\begin{array}{l}\text { Colorless end cells. Resting cells in } \\
\text { series, long-cylindrical, smooth. }\end{array}$ & 1 \\
\hline $\begin{array}{l}\text { S. fulginosa } \\
\text { [Sensu Tilden] }\end{array}$ & $20-46-(70)$ & $10-20$ & Coast of Hawaii, USA & $\begin{array}{l}\text { Wide-spread lamellate sheath, coi- } \\
\text { ling noted by Geitler. }\end{array}$ & 2,3 \\
\hline $\begin{array}{l}\text { S. pilosa } \\
\text { Syn Calothrix } \\
\text { Syn Setchelliella }\end{array}$ & $10-40$ & $10-20$ & Widespread Distribution & $\begin{array}{l}\text { Black filaments erect on coast } \\
\text { rocks. }\end{array}$ & 4 \\
\hline \multicolumn{6}{|l|}{$\underline{\text { Non-Marine }}$} \\
\hline S. ambigua & $9-12-(15)$ & $5-8$ & Thermal species, Japan & $\begin{array}{l}\text { Colorless end cells, coiling in fila- } \\
\text { ments }\end{array}$ & 5,6 \\
\hline S. calotrichoides & $6-8(11)$ & (2) $6-7$ & Tropcial inland waters & $\begin{array}{l}\text { Colorless end cells. Branching al- } \\
\text { most always single. }\end{array}$ & 7 \\
\hline S. contorta & (6) $14-30$ & (3) $9-12-(13)$ & $\begin{array}{l}\text { Tropical, Waterfall splash zo- } \\
\text { nes on Hawaii }\end{array}$ & $\begin{array}{l}\text { Profuse coiling and double false } \\
\text { branching, non-lamellate sheath, } \\
\text { round or ellipsoidal spores someti- } \\
\text { mes vacoulized }\end{array}$ & 8 \\
\hline S. ghazipurensis & (7) $14-27$ & (5)10-17 & Tropical, Paddy field, India & $\begin{array}{l}\text { Apical cutting present, wide shea- } \\
\text { ths. }\end{array}$ & 9 \\
\hline S. hydnoides & $13-22$ & $(2.5-3.5) 5-10$ & $\begin{array}{l}\text { Thermal, from Yellowstone } \\
\text { National Park, USA }\end{array}$ & $\begin{array}{l}\text { Wide-flaring lamellated sheath } \\
\text { ends, colorless end cells, and extre- } \\
\text { mely long heterocytes }(20-90 \mu \mathrm{m}) \text {, } \\
\text { resting cells in series. }\end{array}$ & 2 \\
\hline S. incerta & $(3-6) 7-9(10)$ & $(2-3) 6$ & $\begin{array}{l}\text { Tropical (Geitler), and from } \\
\text { Paddy Fields, India }\end{array}$ & $\begin{array}{l}\text { Small amount of coiling noted by } \\
\text { Geitler. }\end{array}$ & 7,10 \\
\hline $\begin{array}{l}\text { S. kashyapi } \\
\text { Syn Spleaopogon }\end{array}$ & $4.5(7)$ & $(4) 6$ & $\begin{array}{l}\text { Tropical, on Ceratophyllum } \\
\text { in stagnant pond, Benaras, } \\
\text { India }\end{array}$ & $\begin{array}{l}\text { No apical cutting, single false bran- } \\
\text { ching, longer than wide cells }(2-4 x) \\
\text { throughout the length of the fila- } \\
\text { ment, thick and smooth walled spo- } \\
\text { res in chains. }\end{array}$ & 11 \\
\hline S. neocaledoniense & $5-9$ & $2-5$ & $\begin{array}{l}\text { Tropical-Terrestrial, forest } \\
\text { soils of New Caledonia }\end{array}$ & $\begin{array}{l}\text { Diagnosed by its sharp apex. Has } \\
\text { longer than wide cells }(2-3 x) \text { throu- } \\
\text { ghout the length of the filament. }\end{array}$ & 12 \\
\hline S. shankargarhensis & $\begin{array}{l}(11-) 12- \\
16(19)\end{array}$ & $\begin{array}{l}(5-7) 9-12 \\
(-13)\end{array}$ & $\begin{array}{l}\text { Tropical, paddy field, near } \\
\text { Allahabad, India }\end{array}$ & $\begin{array}{l}\text { Apical cutting present. Compared to } \\
\text { S. terrestris, heterocysts longer, less } \\
\text { frequent branching. }\end{array}$ & 10 \\
\hline S. starmachii & $\begin{array}{l}8-9.3-18.6- \\
21\end{array}$ & $5-7-9.3-11.6$ & $\begin{array}{l}\text { High Elevation Lake, High } \\
\text { Tatra Mountains }\end{array}$ & $\begin{array}{l}\text { Colorless end cells, Ammatoidea } \\
\text { and Calothrix like stages, controlled } \\
\text { reproduction of heterocytes, double } \\
\text { false branching. }\end{array}$ & 1 \\
\hline S. terrestris & $\begin{array}{l}(6-7) 10-13(- \\
14)\end{array}$ & $(3.5-6) 8-11$ & $\begin{array}{l}\text { Tropical/paddy field, near Al- } \\
\text { lahabad, India }\end{array}$ & $\begin{array}{l}\text { Apical cutting present. Compared } \\
\text { to } S \text {. shankargarensis, Heterocytes } \\
\text { short, more frequent branching. }\end{array}$ & 10 \\
\hline S. woronichinii & $\begin{array}{l}(8-) 9- \\
10(10-5)\end{array}$ & (4) $6.5-8$ & $\begin{array}{l}\text { Tropical, paddy field in Tur- } \\
\text { kestan }\end{array}$ & $\begin{array}{l}\text { The type species. Apical cutting } \\
\text { present. The spores are quite long } \\
(10-19 \mu \mathrm{m}) .\end{array}$ & 13,14 \\
\hline \multicolumn{6}{|l|}{$\underline{\text { Unclear Taxa }}$} \\
\hline Calothrix pulvinata & $15-18$ & $8-12$ & $\begin{array}{l}\text { Marine, widespread Distri- } \\
\text { bution }\end{array}$ & $\begin{array}{l}\text { Colony erect, fasciculated. The } \\
\text { cells are } 1 / 2 \text { to } 1 / 3 \text { long as wide. Very } \\
\text { abruptly tapered. }\end{array}$ & 15 \\
\hline Calothrix vivipara & $12-24$ & $9-15$ & $\begin{array}{l}\text { Marine, widespread distri- } \\
\text { bution }\end{array}$ & Double false branching reported. & 16,17 \\
\hline Tildenia dura & $\begin{array}{l}23-34.5- \\
(98.8)\end{array}$ & (8) $-9.2-14.3$ & $\begin{array}{l}\text { Marine, Gulf of Mexico and } \\
\text { California Coast }\end{array}$ & $\begin{array}{l}\text { Limestone encrusted colony, wide } \\
\text { spreading lamellate sheath, coiling } \\
\text { in filaments }\end{array}$ & 18 \\
\hline
\end{tabular}




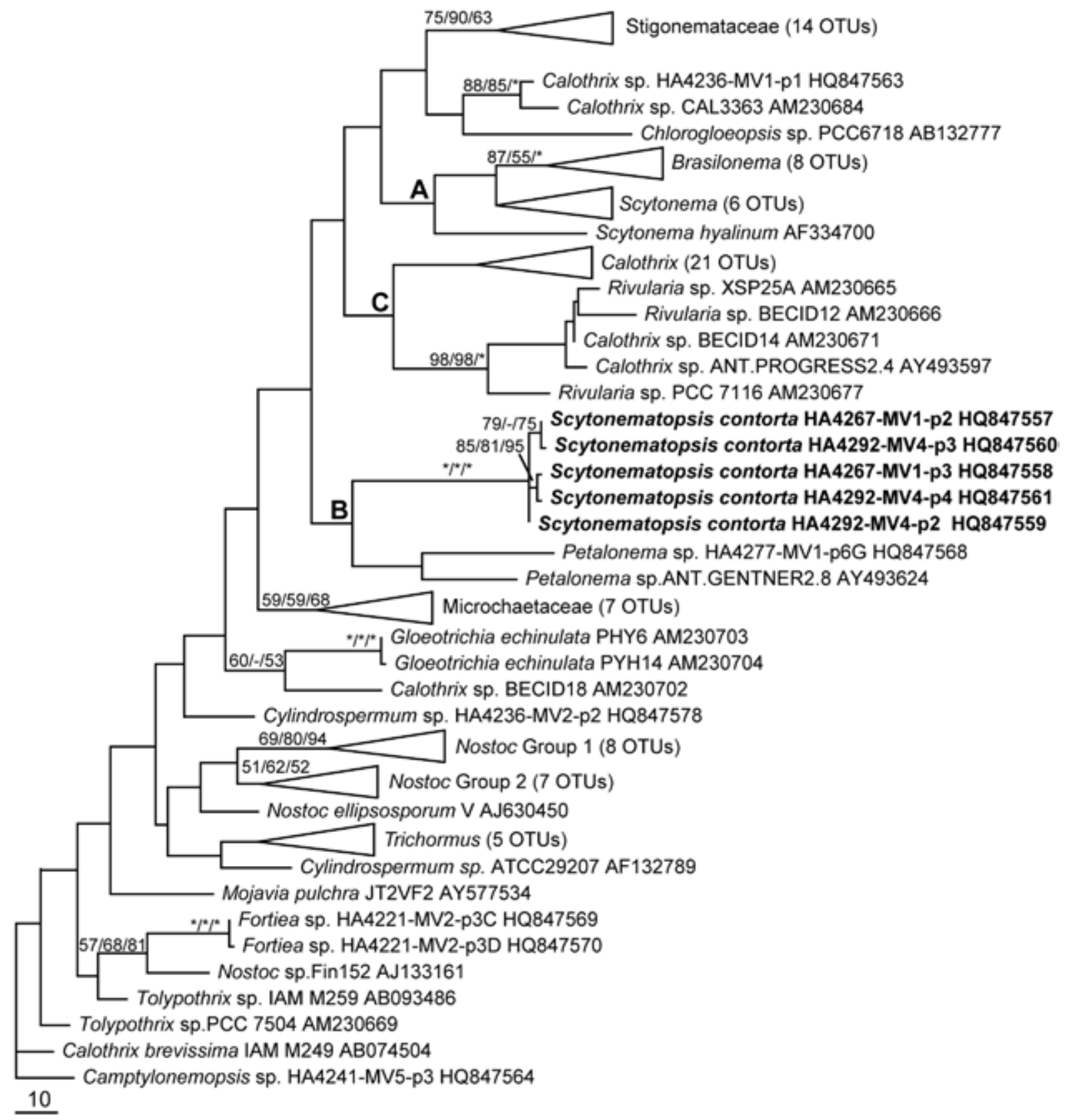

Fig. 18. Parsimony tree of phylogenetically close taxa in the Microchaetaceae, Scytonemataceae, and Stigonemataceae, with representative Nostocaceae as outgroup taxa. Clades of related taxa distant from Scytonematopsis were collapsed. Bootstrap values at supported nodes ( $>50 \%)$ are given for parsimony, maximum likelihood, and distance, respectively. An asterisk equals a value of 100 . Scale number of evolutionary steps.

were combined into a single family, they would not form a supported monophyletic taxon (Fig. 18).

The Rivularia clade (containing two Calothrix species) had high bootstrap support in all analyses, and was sister to Calothrix. The Calothrix clade consisted of three supported clusters having very high bootstrap support $(\geq 98 \%$ in all three analyses, not shown). The Brasilonema and Scytonema clades occured as sister taxa. The
Scytonema clade formed two distinct clusters with high bootstrap support $(\geq 99 \%$ in all three analyses, not shown). Brasilonema formed a monophyletic cluster. This grouping was supported in each analysis, with highest bootstrap support using distance $(100 \%)$. The Stigonemataceae was made up of two supported distinct clusters, the Fisherella/Hapalosiphon (node support 87/79/99) and thermal Mastigocladus (node support 100/98/100) clades (not shown). 
Table 2. Percent similarity matrix for 14 strains of comparison using a 1123 nucleotide partial sequence of the 16S rRNA gene [Strain access numbers: (1) HA4292-MV4-p2, HQ847559; (2) HA4267-MV1-p3, HQ847558; (3) ANT.GENTNER2.8, AY493624; (4) HA4277-MV1p6G, HQ847568; (5) AF334697; (6) HA4186-MV5-p10AB, HQ847580; (7) BECID14, AM230671; (8) HAF2-B2-c1-p11 A, HQ847553; (9) AF236651; (10) PCC 7110, AM709637; (11) HA4187-MV1-p1H, HQ847567; (12) SRS6, AF334692; (13) PYH6, AM230703; (14) CM1VF14, AY577537].

\begin{tabular}{|c|c|c|c|c|c|c|c|c|c|c|c|c|c|}
\hline & 1 & 2 & 3 & 4 & 5 & 6 & 7 & 8 & 9 & 10 & 11 & 12 & 13 \\
\hline 1. Scytonematopsis contorta & - & & & & & & & & & & & & \\
\hline 2. Scytonematopsis contorta & 99.55 & - & & & & & & & & & & & \\
\hline 3. Petalonema $\mathrm{sp}$. & 92.96 & 93.06 & - & & & & & & & & & & \\
\hline 4. Petalonema sp. & 92.16 & 92.06 & 95.31 & - & & & & & & & & & \\
\hline 5. Calothrix parietina & 91.20 & 91.21 & 91.12 & 90.40 & - & & & & & & & & \\
\hline 6. Calothrix sp. & 91.97 & 91.98 & 91.98 & 91.52 & 97.56 & - & & & & & & & \\
\hline 7. Rivularia $\mathrm{sp}$. & 92.32 & 92.15 & 92.96 & 92.32 & 90.75 & 91.24 & - & & & & & & \\
\hline 8. Scyotnema sp. & 89.90 & 89.62 & 90.89 & 90.43 & 89.76 & 89.71 & 90.87 & - & & & & & \\
\hline 9. Scytonema hyalinum & 91.49 & 91.59 & 93.86 & 93.76 & 91.65 & 91.41 & 92.21 & 91.22 & - & & & & \\
\hline 10. Scytonema hofmanii & 91.38 & 91.67 & 93.95 & 93.48 & 90.45 & 91.12 & 90.57 & 89.95 & 93.21 & - & & & \\
\hline 11. Brasilonema sp. & 92.16 & 92.43 & 94.15 & 94.15 & 91.85 & 91.80 & 93.23 & 92.25 & 94.67 & 93.58 & - & & \\
\hline 12. Spirirestis rafaelensis & 92.97 & 92.69 & 95.50 & 94.69 & 91.31 & 91.79 & 93.31 & 90.00 & 92.51 & 92.77 & 92.44 & - & \\
\hline 13. Gloeotrichia echinulata & 91.50 & 91.42 & 93.34 & 93.15 & 90.58 & 91.97 & 92.68 & 89.52 & 92.14 & 90.87 & 92.07 & 94.77 & - \\
\hline 14. Nostoc desertorum & 91.61 & 91.33 & 94.87 & 93.15 & 89.58 & 90.34 & 90.96 & 89.27 & 91.96 & 92.23 & 91.45 & 94.61 & 93.61 \\
\hline
\end{tabular}

\section{Secondary structures}

Secondary structures including the D1-D1' helix, Box-B helix, and V3 helix were determined for several available operons of representative strains included in the phylogenetic analysis. Visual comparison of these structures often showed a high degree of variability between genera, as well as significant variability between operons within single strains.

The D1-D1' helix was highly variable among the different genera reported, with all genera forming distinctive structures (Figs 1926). Past studies of the secondary structure of ITS regions have demonstrated that the basal portion of the D1-D1' helix is typically conserved in closely related taxa (К̌́eHÁKOvÁ et al. 2007; JoHANSEN et al. 2008; SiegESMUND et al. 2008; LuKešová et al. 2009). This group of Nostocales was unusual in that none of the structures were identical. All Scytonematopsis contorta D1-D1' helices were the same, and had a 6 bp helix subtending the unilateral bulge (Fig. 19). The structurally most similar helix was found in Nostoc desertorum (Fig. 20), a taxon quite distantly related to Scytonematopsis based on phylogenetic analysis (Fig. 18). The most distinctive and different helices could be found in Brasilonema (Figs 24-24) and Petalonema (Fig. 36). While common motifs have been identified for Nostoc (ŘEHÁKovÁ et al. 2007; LuKEŠOvÁ et al. 2009) and the Microchaetaceae (CASAMATTA et al. 2006), the Scytonemataceae and Rivulariaceae as presently defined do not appear to have such common motifs. In one instance, we show the marked variability between operons from the same strain, Brasilonema HA4187-MV1 (Figs $24,25)$.

The Box-B helix for $S$. contorta was also distinct (Figs 27-34). Although it had the identical basal structure and sequence (a 4 bp helix), it was longer than all other Box-B helices and had a different apical sequence (Fig. 27). The two operons in Brasilonema shared identical Box-B helices (Figs 32, 33). All other Box-B helices were different from one another.

Because $S$. contorta lacked tRNA genes in all recovered ITS regions, it had no V2 helix. The V3 helix, however, was present in all taxa. $S$. contorta clearly had the longest V3 helix of any species examined (Figs 35-42). There was insufficient similarity in any of these helices to make inferences about phylogenetic relationships.

An examination of the percent similarity $(100 *(1-\mathrm{P}))$ revealed a similarity of $99.55-$ $100.00 \%$ between the two populations of $S$. contorta (Table 2), with most of the variability attributable to different operons. The next most similar strains based on this simple metric were Petalonema (92.96-93.06\%) and Spirirestis (92.69-92.97\%). All other representative taxa in Table 2 were less than $92.5 \%$ similar to both populations (Table 2), and indeed were not similar 


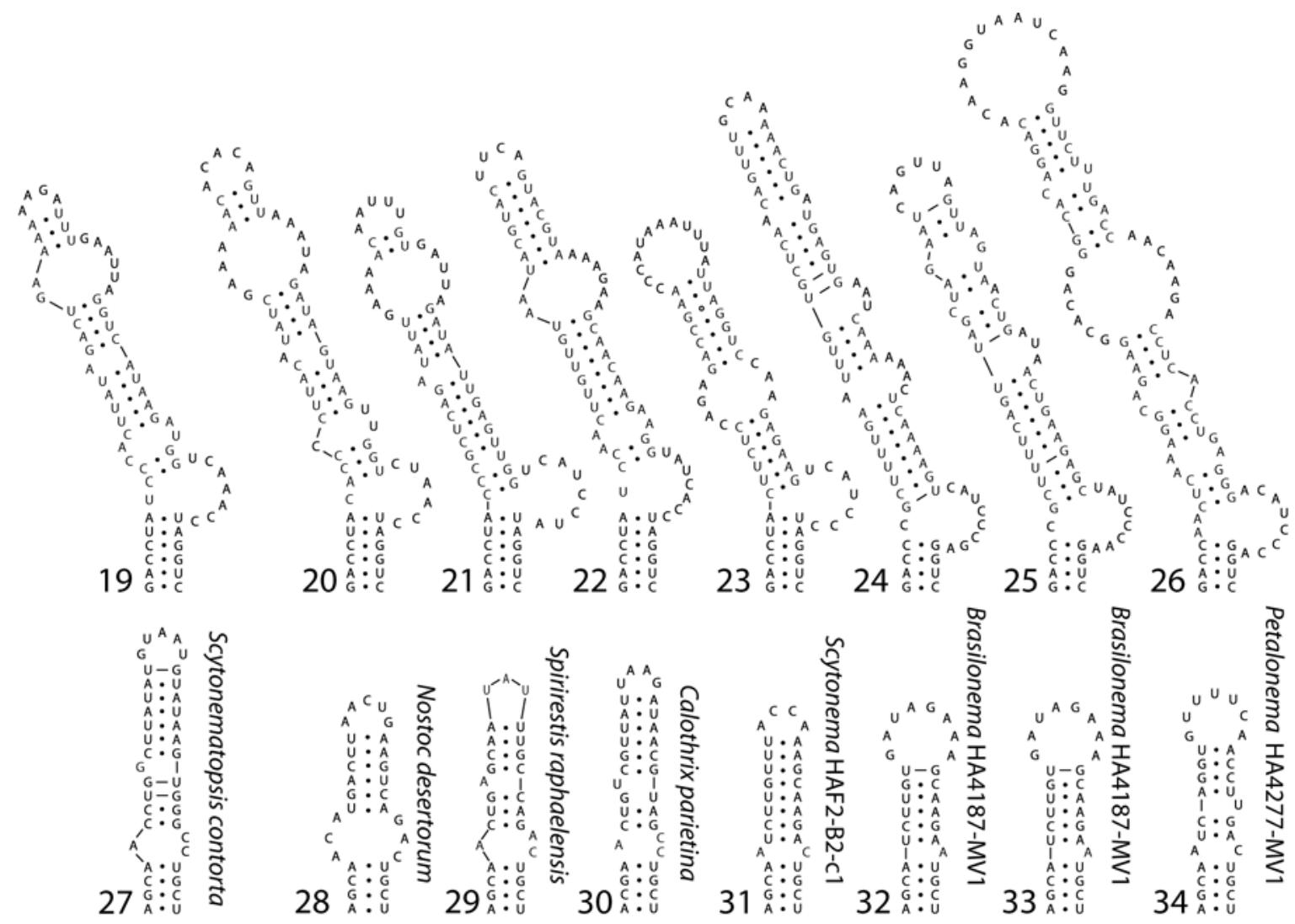

Figs 19-34. Secondary structure of ITS regions in phylogenetically close taxa: (19-26) D1-D1' helices; (27-34) Box-B helices. Structures from the same taxa and operon are aligned vertically. Taxon accessions listed in Table 2.

to each other at all. The deep genetic divergence in these taxa suggests that our taxon sampling of the group is insufficient, and we will need many more taxa before the phylogeny of the tapering Nostocales can be well resolved.

\section{Discussion}

Our strains certainly fit the current description of Scytonematopsis in terms of morphology. The geminate false branching, coiling within filaments, isopolarity, and tapering towards the ends clearly affiliate $S$. contorta with the freshwater species in the genus. However, the higher level taxonomy is uncertain. The node containing our species was well supported, but its position in the tree was not. Furthermore, it was more proximal to the Rivulariaceae than the Scytonemataceae. It is very clear that heteropolar tapering taxa such as Rivularia and Calothrix have a confused taxonomy. Calothrix is especially problematic, falling into at least four different clades in our tree. Others have determined Calothrix to be present in 4-5 clades as well (Sihvonen et al. 2007; Berrendero et al.
2008). While we do not have definitive evidence, it appears that Scytonematopsis actually belongs in the Rivulariaceae.

It seems very likely that Scytonematopsis is polyphyletic. Given the wide ecological range in which species occur (tropical marine, tropical paddy soils, tropical aerial habitats, temperate freshwater, thermal springs, etc.) it seems likely that there may at least be a freshwater/marine dichotomy. We need to have greater taxon sampling in the genus to establish the monophyly or polyphyly of the genus. The Rivulariaceae are in need of revision, and not all recent work has contributed to that revision. The type species for Calothrix is marine: Calothrix confervicola Agardh ex Bornet et Flahault (1886), while the type species for Rivularia is freshwater: Rivularia dura Roth ex Bornet et Flahault (1886). It seems unfortunate to us that RIPPKA et al. (2001) decided to place all marine strains of tapering cyanobacteria in Rivularia, and all freshwater strains in Calothrix. This decision contradicts the principle of taxonomic priority and ignores nomenclatural rules. If Scytonematopsis were included in the Rivulariaceae, narrowly defined it 


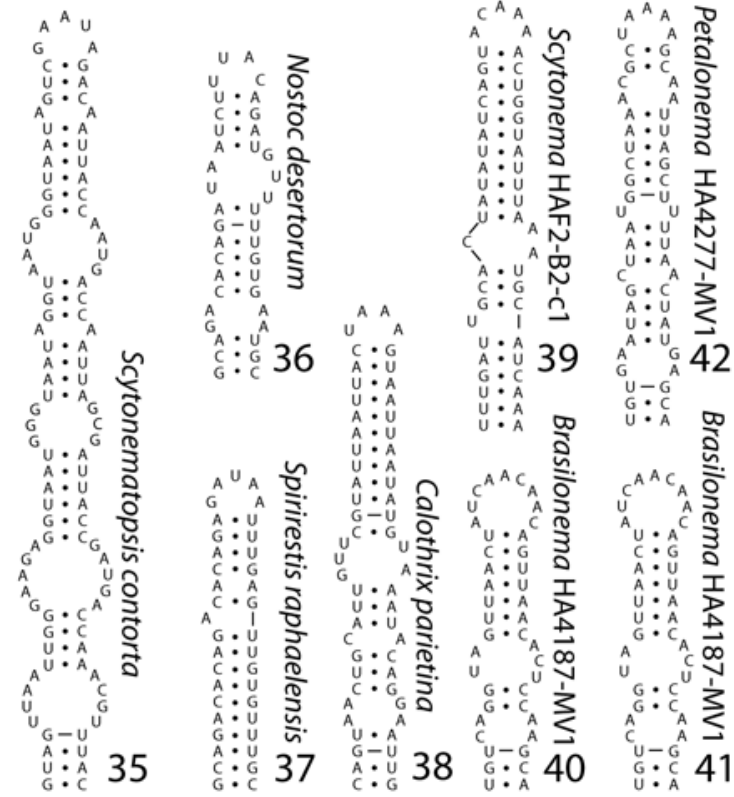

Figs 35-41. V3 structures from 16S-23S ITS regions in phylogenetically close taxa. Taxon accessions listed in Table 2 .

would include isopolar freshwater taxa. Calothrix should be represented by the heteropolar marine taxa, and Rivularia should contain the heteropolar freshwater taxa. Additional freshwater Calothrixlike taxa would need diagnosis and one or more new genera. BERRENDERO et al. (2008) noted that one clade of freshwater tapering species in their study belonged in a new genus, but they did not erect the taxon in that paper.

One unusual finding was the phylogenetic placement of Fortiea in the Nostocaceae rather than the Microchaetaceae where it is typically placed (KomÁreK \& ANAGNostidis 1989). This rare and poorly studied genus is characterized by unbranched heteropolar filaments which have a basal heterocyte and are widened at the opposite end. We do not feel we have enough taxon sampling in this group to come to a definitive conclusion regarding the familial taxonomy of this genus, but suspect that the Microchaetaceae narrowly defined includes only taxa capable of at least some false branching. Further study in this genus is planned for future work, as we have isolated two strains from Hawaii in this genus.

We were surprised by the variability in the secondary structures of the 16S-23S ITS region. This high level of variability indicates that the representatives in the combined Scytonemataceae and Rivulariaceae are actually deeply divergent. Some taxa, such as Brasilonema species, had highly similar secondary structures (data not shown). However, putative sister taxa, such as Scytonematopsis and Petalonema, were quite distinct, indicating a long evolutionary history since their last common ancestor. It is also unsettling to consider placement of Petalonema in the Rivulariaceae based on its placement in the phylogeny in this paper.

In previous papers, we have found a high level of conservation in the secondary structure of the D1-D1' helix and Box-B helix among Pseudanabaenales (JoHANSEN et al. 2008; JOHANSEN et al. 2011; BoHUNICKÁ et al., this issue), the Phormidiales (SiEgesmund et al. 2008), and selected Nostocales (ř́нÁ́KovÁ et al. 2007; LuKEŠOvé et al. 2009). We suspect that with more taxon sampling, we would begin to see similar patterns in the Rivulariaceae and Scytonemataceae. It is critical in this work to try to obtain the same operons between taxa (distinguishable by the presence or absence of tRNA genes). We tried to obtain an operon for Scytonematopsis with both tRNA genes, but did not recover one in the seven sequences we cloned. It may be that this genus does not have operons with tRNA genes, or it could have a mutation in the primer region that prevents us from obtaining that particular operon.

\section{Acknowledgments}

This work was completed with support from National Science Foundation grant number DEB-0842702. Any opinions, findings, conclusions, or recommendations expressed in this material are those of the authors and do not necessarily reflect the views of the National Science Foundation. We would like to thank the Hawaiian Algal Freshwater Team: Dr. Alison Sherwood, Dr. Amy Carlile, and Jessica Newman at the University of Hawaii at Manoa; Dr. Patrick Kociolek and Carrie Graeff at the University of Colorado at Boulder; Dr. Rex Lowe at Bowling Green University; and Alex Valigosky at John Carroll University for their collecting efforts. Furthermore, we would like to thank Dr. Mike Martin for his guidance and use of the molecular lab, and Karina Osario-Santos, Petr Dvořák, Gulshat Bakieva, Victor Edrenkin, and Deni Klein for their support and assistance. We also thank Dr. Jiří Komárek and Dr. Tomáš Hauer for the use of the library at the Czech Academy of Sciences Botanical Institute and their help in locating some of the obscure literature.

\section{References}

AkiYama, M. (1977): Illustrations of the Japanese fresh-water algae. - 933 pp., Uchidarokakuho Publ. Col., Ltd. Japan. 
Berrendero, E., Perona E. \& Mateo, P. (2008): Genetic and morphological characterization of Rivularia and Calothrix (Nostocales, Cyanobacteria) from running water. - International Journal of Systematic and Evolutionary Microbiology 58: 447-460.

Bornet, E. \& Flahault, C. (1886): Revision des Nostocacées héterocystées. - Ann. Sci. Nat. Bot. 7: 323-370.

Boyer, S.L., Flechtner, V.R. \& Johansen, J.R. (2001): Is the $16 \mathrm{~S}-23 \mathrm{~S}$ rRNA internal transcribed spacer (ITS) region a good tool for use in molecular systematics and population genetics? A case study in cyanobacteria. - Molecular Biology and Evolution 18: 1057-1069.

Boyer, S.L., Johansen, J.R. \& Flechtner, V.R. (2002): Characterization of the $16 \mathrm{~S}$ rRNA gene and associated 16S-23S ITS region in Microcoleus: evidence for the presence of cryptic species in desert soils. - Journal of Phycology 38: 12221235.

Casamatta, D.A., Gomez, S.R. \& Johansen, J.R. (2006): Rexia erecta gen. et sp. nov. and Capsosira lowei sp. nov., two newly described cyanobacterial taxa from the Great Smoky Mountain National Park (USA). - Hydrobiologia 561: 13-26.

CARMichael, W.W.(1986): Isolation, culture and toxicity testing of toxic freshwater cyanobacteria (bluegreen algae). - In: SHILov, V. (ed.): Fundamental Research in Homogenous Catalysis 3. - pp. 1249-1262, Gordon \& Breach, New York.

Copeland, J.J. (1936): Yellowstone thermal Myxophyceae. - In: Schwartz, H.F. \& Miner, E.T. (eds): Ann. Nat. Sci. 36. - 232 pp., The New York Academy, New York.

Couté, A., Tell, G. \& Thérézien, Y. (1999): Cyanophyceae (Cyanobacteria) aérophiles de Nouvelle-Calédonie. - Cryptogamie, Algol. 20: 301-344.

Crispim, C.A., Gaylarde, P.M., Gaylarde, C.C. \& NeIlan, B.A. (2006): Deteriogenic cyanobacteria on historic buildings in Brazil detected by culture and molecular techinques. International Biodeterioration \& Biodegredation 57: 239-243.

Desikachary, T.V. (1959): Cyanophyta. - In: Desikachary, T.V. (ed.): Indian Council of Agricultural Research Monographs on Algae. 686 pp., I.C.A.R, New Delhi, India.

De Toni, J. (1936): Third list of the Myxophyceae. Noter. Nom. Alg. 8: 6.

Eмото, Y. \& Hirose, H. (1952): Study of the Thermal Flora of Japan. (XXIX). Thermal flora of hot springs in Nagano Prefecture. 3. Bacteria and algae of the Yamanouchi (Hirao) thermal springs. - J. Balneol. Soc. Jap. 5: 17-25.

Geitler, L. (1932): Cyanophyceae. - In: Rabenhorst, L. (ed.): Kryptogamenflora von Deutschland,
Österreich und der Schweiz, vol, XIV, Reprinted 1985. - 1196 pp., Koeltz Scientific Books, Königstein, Germany.

Geitler, L. (1933): Diagnosen neuer Blaualgen von den Sunda-Inseln. - Arch. Hydrobiol./Suppl. 12, Tropische Binnengew. 4: 622-634.

Geitler, L. \& Ruttner, F. (1935): Die Cyanophyceen der Deutschen limnologischen SundaExpedition. - Arch. Hydrobiol./Suppl. 14, Tropische Binnengew. 6: 308-483

Johansen, J.R., Olsen, C.E., Lowe, R.L., Fučíková, K., \& Casamatta, D.A. (2008): Leptolyngbya species from selected seep walls in the Great Smoky Mountains National Park. - Algological Studies 126: 21-36.

Johansen, J.R., Kovacik, L., Casamatta, D.A., FuČíKOVÁ, K., \& KAŠTOVSKÝ, J. (2011): Utility of 16S-23S ITS sequence and secondary structure for recognition of intrageneric and intergeneric limits within cyanobacterial taxa: Leptolyngbya corticola sp. nov. (Pseudanabaenaceae, Cyanobacteria). - Nova Hedwigia 92: (in press).

Kiseleva, E. (1930): About a new bluegreen algae Scytonematopsis woronichinii. - Zhurn. Russk. Bot. Obshch. 15: 169-174.

KomáreK, J. \& Anagnostidis, K. (1989): Modern approach to the classification system of Cyanophytes 4-Nostocales.-Arch. Hydrobiol./ Algological Studies 56: 247-345.

KomÁreK, J. \& Anagnostidis, K. (2005): Cyanoprokaryota -2. Teil/ 2nd Part: Oscillatoriales. - In: BÜdel, B., KRIENITZ, L., Gärtner, G. \& Schagerl, M. (eds): Süsswasserflora von Mitteleuropa 19/2. - 759 pp., Elsevier/Spektrum, Heidelberg.

KosinsKaJA, E.K. (1948): Key for the determination of the marine blue-green algae. - 278 pp., Izd. AN SSSR, Moskva - Leningrad.

KovÁčıK, L'. \& KomÁrek, J. (1988): Scytonematopsis starmachii, a new cyanophyte species from the High Tatra Mts. (Czechoslovakia). - Arch. Hydrobiol./Algological Studies 50-53: 303314.

Lukešová, A., Johansen, J. R., Martin, M.P. \& Casamatta, D. A. (2009): Aulosira bohemensis sp. nov.: further phylogenetic uncertainty at the base of the Nostocales (Cyanobacteria). Phycologia 48: 118-129.

PANDEY, D.C. (1965): A study on the algae from paddy field soils of Ballia and Ghazipur Districts of Uttar Pradesh, India. Part II (A): Taxonomic Considerations - Cyanophyceae. - Nova Hedwigia 10: 177-221

Pandey, D.C. \& Mitra, A. K. (1972): Interesting observations on anew species of Scytonematopsis (S. ghazipurensis n. sp.) - Hydrobiologia 44: 365-367. 
RipPKa, R., Castenholz, R.W. \& Herdman, M. (2001): Subsection IV. - In: Boone, D.R. \& CASTENHOLZ, R.W. (eds): Bergey's Manual of Systematic Bacteriology, Vol. 1. - pp. 562-589, Springer, New York.

Řeháková, K., Johansen, J.R., Casamatta D.A., Li, X. \& Vincent, J. (2007): Morphological and molecular characterization of select desert soil cyanobacteria: three species new to science including Mojavia pulchra gen. et sp. nov. Phycologia 46: 481-502

Siegesmund, M.A., Johansen, J.R., Karsten, U. \& FriedL, T. (2008): Coleofasciculus gen. nov. (Cyanobacteria): Morphological and molecular criteria for revision of the genus Microcoleus Gomont. - Journal of Phycology 44: 15721585.

Sihvonen, L.M., Lyra, C., Fewer, D.P., RajaniemiWacklin, P., LehtimäKi, J.M., Wahlsten, M. \& Sivonen, K. (2007): Strains of the cyanobacterial genera Calothrix and Rivularia isolated from the Baltic Sea display cryptic diversity and are distantly related to Gloeotrichia and Tolypothrix. - FEMS Microbiology Ecology 61: 74-84.

Swofford, D.L. (1998): PAUP*: Phylogenetic Analysis Using Parsimony (and Other Methods) Sunderland, MA: Sinauer Associates
TiLden, J. (1910): MinnesotaAlgae. I. The Myxophyceae of North America and Adjacent Regions. - 302 pp., University of Minnesota, Minneapolis, Minnesota.

UmezaKi, I. \& Watanabe, M. (1994): Enumeration of the Cyanophyta (blue-green algae) of Japan. Jpn. J. Phycol. 42: 175-219.

VARMA, A.K. (1974): Scytonematopsis Kisselewa from Indian rice field soils. - Nova Hedwigia Beih. 47: 625-635.

YonedA, Y. (1952): A general consideration of the thermal Cyanophyceae of Japan. - Mem. Coll. Agr., Kyoto Univ. 62: 1-20.

Zuker, M. (2003): Mfold web server for nucleic acid folding and hybridization prediction. - Nucleic Acids Res. 31: 3406-3415.

(C) Czech Phycological Society (2011)

Recieved Sept 2010

Accepted Dec 2010 